\title{
Beyond Yäkkatit 12 (19 February 1937)
}

\section{Ethiopian Christians and German Missionaries Resisting Together}

If there is any room after the assassination attempt to interact closely with the natives - and Mr Rathje as a missionary was always doing that day-in, day-out, throughout the past year - and to remain innocent, then we are certainly innocent. However, if in our situation there is no room anymore to be innocent in the eyes of the Italians, only then are we also guilty. There will be nothing that can be done about that. ${ }^{1}$

\section{Introduction}

Resistance, both passive and active, can be described as a counter-movement to stop any state, system, power or ideology that acts against the freedom of a nation and its people. For Christians, resistance is justified or required when evil powers violate fundamental human rights or human dignity, which is against the law of God. ${ }^{2}$ In Ethiopia, resistance is connected to the ItaloEthiopian war (1934-1936) and the subsequent occupation that ended in $1941 .^{3}$ It is connected to patriotism, liberation and intellectual movements. ${ }^{4}$ It com-

1 Politisches Archiv des Auswärtigen Amts (Political Archive of the Foreign Ministry, PA-AA), RAV Addis Abeba, Berlin, GG4O, Bahlburg-Olivieri, o6.o4.1937. All translations are by the author [JK].

2 Acts 5:29 "We must obey God rather than men" or passages of the Sermon of the Mount (Matthew 5-7) are often used, among other, as parameters for a theology of resistance.

3 Seltene Seyoum, "Resistance," in EAe 4 (2010): 379-380, with the concept of yäwastanna yäwaçç̌i arbäñ̃̃oč (inner and outer patriots); Bahru Zewde, Society, State and History. Selected Essays (Addis Ababa: Addis Ababa University Press, 2008), 383-385. Transcription rules follow EAe 1 (2003): xx-xxi.

4 Bahru Zewde, Society, 215-237.

(C) STANISLAU PAULAU AND MARTIN TAMCKE, 2022 | DOI:10.1163/9789004505254_010

This is an open access chapter distributed under the terms of the CC BY-NC-ND 4.o license 
prises political, economic, sociological and religious factors. Based on the nexus between religion and nation, the religious factor played a pivotal role in Ethiopian history. However, religious or theological motives in Ethiopian resistance movements have not been widely studied. ${ }^{5}$ This article focuses on the German Hermannsburg Mission (GHM) and three of its members: Səbhat Ṭərunäh (1901/11-1937), an Ethiopian teacher at the GHM, and the missionaries Rev. Hermann Bahlburg (1892-1962) and Rev. Hinrich Rathje (1904-1959).

The article explores their roles in resisting together during the incidents around Yäkkatit 12 (19 February 1937), ${ }^{6}$ commemorated since 1942 as yäsäma'atat qän (Martyrs Day). ${ }^{7}$ The research is based on documents found in the archives of the German Foreign Ministry, the Evangelical Lutheran Mission Hermannsburg, in the private archives of the families Bahlburg and Rathje, on interviews and secondary literature. The objectives include highlighting the complexities of GHM's involvement in the resistance and questioning the methodology for the reconstruction of history in the account of I. Campbell's book The Plot to Kill Graziani (2010), which deals extensively with the GHM. ${ }^{8}$ The first part describes the political and religious context of Yäkkatit 12. The second part analyses different accounts of the events during those days. The

5 A discussion of a theology of resistance referring to Dietrich Bonhoeffer (1906-1945) and Guddinaa Tumsaa (1929-1979), as an example of Ethiopian-German interconnectedness, is beyond the scope of this article. Both represent models of active and passive resistors against different sets of unbearable totalitarian state ideologies. See Paul Wee, "Dietrich Bonhoeffer and Gudina Tumsa. Shaping the Church's Response to the Challenges of Our Day," in Church and Society. Lectures and Responses. Second Missiological Seminar 2003 on the Life and Ministry of Gudina Tumsa, ed. Gudina Tumsa Foundation (Hamburg: WDL-Publ., 2010), 15-51, referring to both, on the question of critical solidarity with the state turning against it.

6 Pawlos Ñoño, The Ethiopian-Italian War [in Amharic], 2nd ed. (Addis Ababa: Addis Ababa University Press, 2009 A.M.-2017), 158-170; Angelo Del Boca, "Faschismus und Kolonialismus. Der Mythos von den 'anständigen Italienern', in Völkermord und Kriegsverbrechen in der ersten Hälfte des 20. Jahrhunderts, ed. Fritz Bauer Institut (Frankfurt am Main: Campus, 2004), 197; Ian Campbell, The Plot to Kill Graziani. The Attempted Assassination of Mussolini's Viceroy (Addis Ababa: Addis Ababa University Press, 2010), 452-455 (Chronology); Ian Campbell, The Massacre of Debre Libanos. Ethiopia 1937. The Story of One of Fascism's Most Shocking Atrocities (Addis Ababa: Addis Ababa University Press, 2014), 46-53; Ian Campbell, The Addis Ababa Massacre. Italy's National Shame (London: Hurst \& Company, 2017), 4748.

7 Campbell, The Plot, xxxv-xxxix. For the massacres, see: Del Boca, "Faschismus und Kolonialismus"; Campbell, The Addis Ababa Massacre; Seltene Seyoum, Resistance, 379. A monument in Addis Abäba (Arat Kilo) displays the atrocities of the Italians.

8 For a comprehensive review, see: Jürgen Klein, The Reconstruction of Ethiopian History. The Involvement of the German Hermannsburg Mission in the Incidents around Yäkkatit 12 (forthcoming). 
third part deals with how the Germans and Ethiopians resisted the Italians together, and the conclusion synthesizes the main findings. The article aims to reveal aspects of religiously motivated resistance that interconnects Christians transnationally, and beyond Yäkkatit 12.

\section{The Political and Religious Context of Yäkkatit 12}

Understanding the context of the Italian rule in Africa Orientale Italiana (AOI) helps to explain how the actors involved had to deal with the complex setting. An overview of the religious situation of the evangelical missions helps to localize the GHM and the activities of its members within the socio-political landscape of Addis Abäba.

\subsection{The Political Context}

The occupation, with Viceroy Rodolfo Graziani preferring a direct colonial rule, was accompanied by an ongoing resistance of Ethiopian patriots. ${ }^{9}$ The liquidation of the intelligentsia, especially during the massacres, was a systematically planned method to curb resistance. ${ }^{10}$

9 Angelo Del Boca, The Ethiopian War 1935-1941, trans. P.D. Cummins (Chicago: University of Chicago Press, 1969); Aregawi Berhe, "Revisiting resistance in Italian-occupied Ethiopia. The Patriots' Movement (1936-1941) and the redefinition of post-war Ethiopia," in Rethinking Resistance. Revolt and Violence in African History, ed. Jon Abbink, Mirjam de Bruijn and Klaas van Walraven (Leiden: Brill, 2003), 87-113; Aregawi Berhe, "Spirit vs. Warmachine. A Patriotic Resistance to Italian Occupation of Ethiopia (1936-1941)," Aigaforum, 02.27.2015, URL: http://aigaforum.com/articles/Ethiopian-Resistance.pdf, at 16: "The Italians $[. .$.$] could in no way gain control over the vast Ethiopian countryside where the$ resistance was gathering momentum"; Harold Marcus, A History of Ethiopia (Berkeley: University of California Press, 1994), 148: "Never in their quinquennium of rule did the fascists feel secure in Ethiopia, and their anxiety came to border on neurosis"; Del Boca, The Ethiopian War, 236: "[...] only 300,ooo Italians were absorbed into Ethiopia, more than a third of whom were soldiers" 1939, about 39, ooo of them lived in Addis Abäba. See further: Bahru Zewde, A History of Modern Ethiopia: 1855-1991, 2nd ed. (Addis Ababa: Addis Ababa University Press, $\left.{ }^{2} 2005\right),{ }^{150-177}$ and 375-39o. For the rule, see: Michael Thöndl, "Mussolinis Ostafrikanisches Imperium in den Aufzeichnungen und Berichten des Deutschen Generalkonsulats in Addis Abeba (1936-1941)," in Quellen und Forschungen aus italienischen Archiven und Bibliotheken 88, ed. Deutsches Historisches Institut in Rom (Tübingen: Max Niemeyer Verlag, 2008), 475; Aregawi Berhe, "Spirit," 14. The order Nessun potere ai Ras ("No power to the lords"), was given in August 1936.

10 Bahru Zewde, Society, 215-237; Szélinger Balázs, ed., Fascist Italian Brutality in Ethiopia, 1935-1937. An Eyewitness Account by Sáska László (aka Ladislas Sava), trans. from Hungarian by Meneczer Béla (Trenton: The Red Sea Press, 2015), 109: “The Italians destroyed 
A system of racial discrimination developed within the Impero (empire). It revealed the hatred which many of the Italians and their allied forces cultivated against the Ethiopians. Racial segregation became part of the city construction plans, but it also was evident in daily relations between the occupants and the natives. ${ }^{11}$ The racist attitude reached its climax during the abominable atrocities of the Vendetta (vengeance) on 19 February 1937 and the following days. ${ }^{12}$ In July 1936 it had been foreseen that the violent character of the Italian rule under Graziani, previously witnessed in Libya, would also erupt in Ethiopia. ${ }^{13}$ In 1937, animosity against the Italians grew steadily because of their atrocities. The public execution of Abunä Pețros (1882-1936), because of his active resistance, was one example. ${ }^{14}$

Of particular interest is the relationship between the Italians and the Germans, both of whom had fascist regimes at home. ${ }^{15}$ Initially, the German gov-

systematically all priests and all chiefs and anybody of superior education; in a word all who could have any influence over the people." PA-AA, Pol 3:209, Richter, J. Nr. 292/37, 24.03.1937: “[...] more than 2000 'better' natives have been deported to Somaliland [...] the night before yesterday, 40 Abyssinians, who had been imprisoned since the assassination attempt on the Viceroy, were shot." Archiv des Ev.-Luth. Missionswerks in Niedersachsen e.V. (Archive of the Evangelical-Lutheran Mission in Lower Saxony, A-ELM), Hermannsburg, Bahlburg-Schomerus, 31.05.1937, 4.

11 Del Boca, The Ethiopian War, 226, 229; Campbell, The Plot, 59; Richard Pankhurst, "Development in Addis Ababa during the Italian Fascist Occupation (1936-1941)," in Proceedings of the International Symposium on the Centenary of Addis Ababa, November 24-25, 1986, ed. Ahmed Zekaria, Bahru Zewde and Taddese Beyene (Addis Ababa: Institute of Ethiopian Studies, 1987), 131-132; Otto Welsch, "Befriedung und Aufbau in Äthiopien," Zeitschrift für Politik 27, no. 9 (1937): 540, URL: https://www.jstor.org/stable/43527536?seq=1\#metadata _info_tab_contents: Racial segregation served for “[...] keeping the Italian race pure [...] since mixed races are an element of social and political disorder and therefore dangerous for the future of the empire."

12 Thöndl, "Mussolinis Ostafrikanisches Imperium," 487. For the massacres in Addis Abäba, see: Campbell, The Addis Ababa Massacre; for Däbrä Libanos, see: Campbell, The Massacre; for Näqämt, see: Aregawi Berhe, "Spirit," 10; for the Ethiopian revolt in Goğğam, see: Thöndl, "Mussolinis Ostafrikanisches Imperium," 487.

13 Matilda Axton et al., ed., Foreign Relations of the United States. Diplomatic Papers, 1936. Vol. 3, The Near East and Africa (Washington: United States Government Printing Office, 1953), 308. Telegram 29.07.1936: "The Ambassador went on to say that he fully expected a 'first-class massacre' in Addis Abäba in the not too distant future. [...] It was the Latin way of doing things, he said, to resort to massacre in order to impress native populations with the authority of Rome."

14 Aregawi Berhe, "Spirit," 9: "The killing of a bishop was unimaginable [...]. It indeed shocked the nation, arousing the indignation of the people and especially the clergy." About the martyrdom of Archbishop Abunä Pețros, see: Pawlos Ñoño, The Ethiopian-Italian War, 156-157; Bahru Zewde, Society, 383; Mersha Alehegne, "Pețros," in EAe 4 (2010): 140-141.

15 Balázs, Fascist Italian Brutality, 103-104. The Italo-German axis refers to the politicalmilitary alliance established 1936. 
ernment secretly provided material and financial support to the empire of Haylä Śllase I. ${ }^{16}$ Controlling the balance of power framed the Italian-German 'friendship', with both observing each other had also been noticed in the relationship between the German Consulate and the AOI in Addis Abäba. ${ }^{17}$ Consulate reports show a critical observation of the Italian methods and their bureaucratic system, which was confirmed by the GHM missionaries. ${ }^{18}$

\subsection{The Religious Context ${ }^{19}$}

The role of native and foreign religious institutions, leaders and adherents as members of the resistance has not previously been dealt with in a comprehensive way, other than in a few Christian (orthodox and protestant) and Muslim participations. ${ }^{20}$ Evangelical engagement was, however, an essential part of the resistance. ${ }^{21}$

16 Edward Westermann, "In the Shadow of War. German Loans and Arms Shipments to Ethiopia, 1935-1936," in New Trends in Ethiopian Studies, Proceedings of the 12th International Conference of Ethiopian Studies, Michigan State University 5-10 September 1994, ed. Marcus Harold (Lawrenceville, NJ: Red Sea Press, 1994), 1036-1050.

17 Thöndl, "Mussolinis Ostafrikanisches Imperium," 451-452. Since October 1936 the Embassy (Gesandtschaft) had been closed and a General Consulate (Generalkonsulat) opened. It was subordinated to the German Embassy in Rome. In 1937, the Consulate was responsible for 184 Europeans, including Germans, Austrians, Swiss and Hungarians. See also: Westermann, "In the Shadow of War," 1038; according to Halldin Norberg, Swedes in Haile Selassie's Ethiopia, 1924-1952: A Study in Early Development Cooperation (Uppsala: Almqvist \& Wiksell, 1977), 66 and 69, the number of Germans was 230 (1.6\% of the foreign population), with 10 from the GHM.

18 Thöndl, "Mussolinis Ostafrikanisches Imperium," 481-482; A-ELM, Bahlburg-Schomerus, 31.05.1937, 3: "The way through the Italian offices is very troublesome, consuming much time and money. Anyone who does not make use of the unclean means of corruption to reach the results wished for feels bullied [...]. But this costs much strength of nerves, strength of soul!" Ibid., 4: "Between the German and Italian authorities exists the wellknown 'friendship'. And everyone is cautious not to let any incident occur that could peeve the 'friend."'

19 Ingeborg Lass-Westphal, "Protestant Missions During and After the Italo-Ethiopian War, 1935-1937," Journal of Ethiopian Studies 10, no. 1 (1972): 89-101; Mikre Sellassie Gebre Ammanuel, Church and Missions in Ethiopia in Relation to the Italian War and Occupation and the Second World War (Addis Ababa: Artistic Printing Enterprise, 2014).

20 For the Ethiopian Orthodox Täwaḩədo Church, see: Aregawi Berhe, "Spirit," 8-9: "The church took it as an everyday obligation, inside and outside the church, to renounce the incursion of Italian invaders." For the nexus of religion and nationalism, see: Mikre Sellassie Gebre Ammanuel, Church and Missions, 172-176. Expressed in the 13th century collection of the Kabrä nägäśt (Nobility of the Kings), the symbiosis of church and state was established with the salomonic dynasty claiming Israelite descent. See Paolo Marrassini, "Kəbrä nägäśt," in EAe 3 (2007): 364. Even though the new constitution (1995) separated state and religion (Art. 11), the Ethiopian Orthodox Church retains its nationalistic identity.

Bahru Zewde, Society, 232-233: “[...] one can suggest tentatively that resistance to Italian 
In 1935, there were ten mission societies in Ethiopia. ${ }^{22}$ The archives provide details about the conditions of the missions in 1936 and 1937, and about the policy of the AOI concerning the religious institutions, churches and missions. ${ }^{23}$ After the shift of power from the Ethiopian imperial to the Italian fascist government, in 1936-1937 only a few mission stations and missionaries remained, working under aggravating circumstances. ${ }^{24}$ Before, during and partly after this new political situation, many mission societies took a pro-Ethiopian stance but remained mostly passive. Some were lobbying in their mother churches and home countries through reports. However, there were others who tried to actively strengthen Ethiopian resistance. ${ }^{25}$ As a result, many missionaries were expelled and mission societies were shut down because of open or alleged antiItalian activities. ${ }^{26}$ The $\mathrm{GHM}$ was also affected. ${ }^{27}$

By 1937 very few protestant missionaries remained. In 1941, only 6 Adventist, 2 Presbyterian and 5 GHM missionaries were active, before the Emperor and British troops arrived. ${ }^{28}$

rule appears to have been most intense among those with an Anglo-Saxon and Protestant educational background [...] Related to this is the prominent role played by the Eritreaneducated elite in the course of the war. Most of these men tended to have a Swedish evangelical background [...]."

22 Lass-Westphal, "Protestant Missions," 91, slightly corrected by Norberg, Swedes, 70. There were four British, two American, one British-American, two Swedish and one German mission societies with a total of 170 missionaries. For the condition of the GHM in 1935, see: Winfried Wickert, Männer und Zeiten. 5o Jahre Hermannsburger Missionsgeschichte. Ein Rückblick (Hermannsburg: Missionshandlung Hermannsburg, 1987), 272-273. For conditions in 1936 and 1937, documents of the Political Archive of the German Foreign Ministry provide further details about the religious situation and policy of the AOI, and how it planned to deal with the religious institutions, churches and missions.

23 PA-AA, G G 4O, Nr. o68, Strohm, 30.09.1936 and 28.12.1936; A-ELM, AE 1.05, Bahlburg-Schomerus, 1937.

24 Lass-Westphal, "Protestant Missions," 97-101, lists the measures taken against the Missions to reduce foreign influence.

25 Lass-Westphal, "Protestant Missions," 94. PA-AA, Richter, J. Nr. GG 40, 06.04.1937. The British Churchmen's Missionary Society's (BCMS) expulsion with German missionary Friedrich Schmidt was politically motivated.

26 In particular, the Swedish Missions and the всмs were shut down, while other mission stations, hospitals of the Sudan Interior Mission, the Adventist and Presbyterian missions and schools in Addis Abäba and elsewhere in Ethiopia were confiscated and had to stop work.

27 The mission station in Bäddällä was evacuated and partly destroyed first. The same happened later in Ayra. GHM missionaries were able to continue their work in Addis Abäba, and in 1938 they resumed work in Ayra.

28 Lass-Westphal, "Protestant Missions," 99. 
The Italians intended to reduce foreign or anti-Italian influence of any sort from their colonial empire-building. Promoting Catholicism over Protestantism was only occasionally reported and 'Italianisation' brought a general strengthening of the Catholic Church in Ethiopia. ${ }^{29}$ Strengthening Ethiopian Islam by supporting the construction of mosques and by facilitating the Hağğ to Mecca was intended to win allies and collaborators, ${ }^{30}$ whereas the Ethiopian Orthodox Church generally has been regarded as an anti-Italian element, loyal to the royal imperial government of Hyaylä Śəllase I. ${ }^{31}$

Far less known than the active resistance efforts that led to martyrdom or direct patriotic attribution is the fact that there had been a strong 'passive' resistance in the underground. Many Ethiopians and foreigners were involved passively in the fight for freedom from injustices, negative racist attitudes and cruel deeds. Identifying those yet unknown participants and 'unsung heroes' is an ongoing process, ${ }^{32}$ in which the Association of Ethiopian Patriots plays an active role. ${ }^{33}$ Members of the evangelical protestant churches

29 On the role of the Catholic Church during the Italo-Ethiopian war and the situation of the protestant missions, see: PA-AA, G G 40, Nr. o68, Strohm, and Bahlburg, 20.10.1936, who deals with the acceptance of the GHM by the AOI, and the relations between church and state. PA-AA, GG 40, Nr. o68, Klee and von Bergen, 13.08.1936, about the Vatican's plan for expansion in Ethiopia. However, see: Mikre-Sellassie Gebre Ammanuel, Church and Missions, 375, who wrote that the Italian government prevented catholic missionary activities. For the treatment of Muslims by the Italians in Libya, see: Aram Mattioli, "Die vergessenen Kriegsverbrechen des faschistischen Italien in Lybien 1923-1933," in Völkermord und Kriegsverbrechen in der ersten Hälfte des 20. Jahrhunderts, ed. Fritz Bauer Institut (Frankfurt am Main: Campus, 2004), 203-226. For the relations between the Italians and Ethiopian Muslims, see: Hussein Ahmed, "Islam and Islamic Discourse in Ethiopia (1973-1993)," in New Trends in Ethiopian Studies, Proceedings of the 12th International Conference of Ethiopian Studies, Michigan State University 5-10 September 1994, ed. Marcus Harold (Lawrenceville, NJ: Red Sea Press, 1994), 775-776; Alberto Sbacchi, Legacy of Bitterness. Ethiopia and Fascist Italy, 1935-1941 (Lawrenceville, NJ: The Red Sea Press, 1997), 162-163; Ahmed Hassen Omer, "Mussolini and Islam in Ethiopia (1922-1941)," in Symposium "Cross and Crescent: Christian-Islamic Relations in Ethiopia," 23.-26.09.2002 (Addis Ababa: Addis Abäba Goethe Institute, 2002), 7-15 (not published). Del Boca, The Ethiopian War, 215, mentioned also the killing of Muslims during the massacres. Narratives of Muslims engaged in resistance can be found at the Ethiopian Association of Patriots in Addis Abäba and in further literature.

31 Aregawi Berhe, "Spirit," 14; Thöndl, "Mussolinis Ostafrikanisches Imperium," 480.

32 Gəzaw Zäwdu, Commemorating Patriotism and a Short History of the Historical Heroes of the Ethiopian Patriots Association [in Amharic] (Addis Abäba, 2016). In this regard, the efforts undertaken by Ian Campbell must be highly appreciated.

33 For the Association of Ethiopian Patriots, see: Richard Pankhurst, "Yäțəntawit Ityopya Ğägnočč Arbäññočč Mahbär," in EAe 5 (2014): 35-36 and Bahru Zewde, "Hagär Fəqər Tiyatər," in EAe 2 (2005): 966-967. 
like Qes Badəmma Yaläw (1885-1973), ${ }^{34}$ Amanu’el Gäbrä Śəllase (1910-1997) ${ }^{35}$ and others participated in passive resistance. ${ }^{36}$ One of the many, yet little known participants in passive resistance was Səbhat Ṭərunäh, the teacher and evangelist of the GHM, who will be introduced later. The leading missionaries of the GHM in Addis Abäba should be mentioned in this regard. Even though the GHM remained as a functioning mission, its work under the given circumstances, framed by a difficult economic situation, was anything but easy. ${ }^{37}$

It was a tense time. The turmoil of May 1936, when the G HM members had to defend their compound against Holäta Military Academy soldiers and others who were marauding after the emperor fled abroad, was still a recent memory. ${ }^{38}$ With the coming events of Yäkkatit 12, they now had to face another shocking wave that again would target the very existence of their mission endeavours in Ethiopia, for which so many sacrifices had already been made. ${ }^{39}$

34 Gustav Arén, Evangelical Pioneers in Ethiopia. Origins of the Evangelical Church Mekane Yesus (Stockholm: EFS Förlaget, 1978), 423-424, 435; Gustav Arén, Envoys of the Gospel in Ethiopia. In the Steps of the Evangelical Pioneers 1898-1936 (Stockholm, E FS Förlaget, 1999), 95, 464, 477, 532; Sven Rubenson, "Badəmma Yaläw," in EAe 1 (2003): 429; Campbell, The Plot, 79 .

35 Johannes Launhardt, “Amanu'el Gäbrä Śəllase," in EAe 1 (2003): 217. In 1941, he became the first President of the Mekane Yesus Congregation of Addis Abäba, and in 1959 the first President of the Ethiopian Evangelical Church Mekane Yesus (E ECMY).

36 For Käntiba Gäbrä Ggzi’abəher Dästa, known as Gäbru Dästa, see: Bairu Tafla, "Gäbrä Ggzi'abəher Dästa," in EAe 2 (2005): 606-6o7; Bahru Zewde, Pioneers of Change in Ethiopia. The Reformist Intellectuals of the Early Twentieth Century (Oxford: Oxford University Press, 2002), 42-47. Members of a special intellectual and social circle that according to Campbell, The Plot, 78-79, included Səbḥat Țərunäh, Mogäs Asgädom, Abrəha Dəboč̣, Mähari Kassa, Colonel Bälay Haylä-Ab, Amanu'el Gäbrä Śəllase and Qes Badəmma Yaläw all had some connections through the Täfäri Mäkwännən School or the Swedish Evangelical Mission (SEM), and were at large part of the 'Intellectual Movement' and network that engaged in some sort of resistance activities.

37 Lass-Westphal, "Protestant Missions," 100: "The fate of the Hermannsburg mission proves clearly that political considerations concerning the mother countries were decisive, since it was allowed to continue, despite the fact that it had taken the Ethiopian side during the conflict, and was not in line (single missionaries excluded) with National Socialist politics." For the economic situation and the situation of foreign currency, see: PA-AA, GG 4O, Nr. o68, Bahlburg-Richter, o6.04.1937.

38 The killing of missionary Adolf Müller (1905-1936) on 11 May 1936, was part of the first shocking wave of the Italian war that affected the GHM. See Ernst Bauerochse, Ihr Ziel war das Oromoland. Die Anfänge der Hermannsburger Mission in Äthiopien (Münster: Lit, 2006), 231-24O; PA-AA, A. Müller (file), 1936.

For the history of the GHM, see: Bauerochse, Ihr Ziel. 


\section{The Events around Yäkkatit 12 from the GHM's Point of View}

Having been caught by surprise about what happened around Yäkkatit 12, the missionaries later recognized some connections to it. Rathje reported on 13 April 1937 that Mogäs Asgädom (1911-1937), one of the two assailants, ${ }^{40}$ was involved in the events: "His [Səbhatu's] friend Mogas, who lived with him, was suspected because he left Addis 14 days before the assassination attempt, in order to drive with an Italian to Jimma". ${ }^{41}$ Other documents confirm that Mogäs was living with Səbhat on the GHM compound for about 8 months, beginning around May 1936 until January 1937 at the latest. Both men helped defend the compound against attacks from 2-5 May 1936. ${ }^{42}$ Both Səbhat (from 1926-1927), and Mogäs (from 1928 on) went to Täfäri Mäkwännən School, a central place for the formation of the intelligentsia (Young Ethiopians). ${ }^{43}$ Together with other friends, they secretly developed plans to fight against Italian oppression. The missionaries were barely aware of these connections. ${ }^{44}$

\subsection{The Chronology of Events ${ }^{45}$}

On Friday, 19 February 1937, the day began as usual on the GHM compound, called Harmshusen, ${ }^{46}$ located in Qäççänä, a city district in the northern part of Addis Abäba, next to the orthodox Mädhane Aläm Church. ${ }^{47}$ Everyone began

40 For Mogäs, see: Matteo Salvadore, "Mogäs Asgädom," in EAe 3 (2007): 984-985; Campbell, The Plot, 15-18, 28-30, 46-47, 68, 75, 90-91, 96-97, 122-124 (Mogäs took a cottage near Harmshusen in December 1936 or January 1937), 150-151, 196-197, 206-219, 247-249, 325354, 361-366 (Mogäs may have been shot at Mätämma, Sudan). Mogäs was the same age as Səbhat, according to Bahlburg's report. For more details, see next sections. The other assailant was Abrəha Däboç, see: Bahru Zewde, "Abrəha Däboç," in EAe 1(2003): 47. A third major accomplice was Səm'on Adäfrəs, who took care of the logistics.

PA-AA, GG 4O, Nr. 068, Rathje-Richter, 13.04.1937; Richard Pankhurst, "Events during the Fascist Occupation: Who was the third man?" Addis Tribune, 27.02.2004. The information about driving to Ǧimma still remains unclear. See further: Campbell, The Plot, 74, 150-154. A-ELM, Bartzsch-Schomerus, 10.05.1936: "Also Sepatu [Səbḥatu], the teacher, was protecting us, and Mogas, an Abyssinian [actually an Eritrean, JK], who lived with us." The time differs from Campbell, The Plot, 77 and 90.

43 Bahru Zewde, Society, 221-226.

44 A-ELM, AE 1.05, Bahlburg-Schomerus, 789, 30.03.1937.

45 PA-AA, G G 40, Nr. o68, Rathje-Richter, 13.04.1937 (My Imprisonment); PA-AA, GG 40, Nr. o68, Bahlburg-Richter (Bahlburg-Olivieri), 06.04.1937; PA-AA, Pol 3:209, GG 4O Rathje; A-ELM, Bahlburg-Schomerus, 06.04.1937 and 29.04.1937.

46 Harmshusen, a name given to the compound in the northern German language Plattdeutsch, literally means Village of Harms, referring to the Mission founder Ludwig Harms (18०8-1865).

For an official Italian map that served propaganda purposes, with some important loca- 
their customary daily activities. ${ }^{48}$ Rathje, who left in the morning to the city for business, was on his way back to Harmshusen before noon when he heard shots, saw fleeing people shouting, and met soldiers with guns at the corner of the Gännäta Lə'ul Palace, the seat of the AOI government. This was where the celebration of the birth of crown prince Vittorio Emanuele (born 12 February 1937) with an alms-giving ceremony had taken place, which was interrupted by the assassination attempt where hand-grenades were thrown at Viceroy Rodolfo Graziani. At about the same time, Bahlburg, who was teaching the first-grade class of the German school on Harmshusen, heard detonations and machinegun fire. At about $2 \mathrm{pm}$ the first refugees were taken in. Bahlburg calmed down the workers in the compound later in the afternoon..$^{49}$ In the evening, a security meeting of the GHM staff took place. On the following days of the weekend, fleeing people again took refuge on Harmshusen. On Saturday, an Italian patrol checked the situation on the GHM compound.

Based on the information provided by spies and interrogated subjects that already had been imprisoned, Səbhat had been caught and taken to prison on March 6 (about two weeks later), and Rathje on April 5 (about six weeks later). ${ }^{50}$ These dates are contrary to Campbell's account, who writes that the

tions in Addis Abäba in 1937, see: Ufficio Superiore Topocartografico, ed., Guida Turistica di Addis Abeba, Riproduzione Vietata 1937 XV (Asmara: A Cura dell'Ufficio Stampa e Propaganda dell'A.O., 1937). For the Gн compound, see: Wickert, Männer und Zeiten, 152, 167-168; Johannes Launhardt, Evangelicals in Addis Ababa (1919-1991): With special reference to Ethiopian Evangelical Church Mekane Yesus and the Addis Ababa Synod (Münster: Lit, 2004), 57, 6o-61; Campbell, The Plot, 13-14. Harmshusen was 36,ooo m $^{2}$ big in size when first bought (later an additional 4,00o $\mathrm{m}^{2}$ have been added).

48 The GHM members, missionaries, families, co-workers and other workers around Yäkkatit 12 included Rev. Hermann Bahlburg (GHM Head in Ethiopia), his wife Minna Bahlburg with their five children; Rev. Hinrich Rathje (Deputy Head); Sister Eva Bartzsch (Nurse); Mrs. Ida Fischer (a guest and teacher); about 10 students at the German School; about 6 Ethiopian children at the orphanage; Max Müller and Fritz Brand (both working on the garden's fence); carpenter Arno Geikler; Ethiopian staff included Səbḥat Ṭərunäh (teacher and evangelist), with his younger brother Taddäsä; a second teacher until December 1936 or January 1937 possibly was Mogäs Asgädom; Gäbrä Ṣadəq Wäldä Mika’el (chauffeur) and his wife (housekeeper); Asrəss (Gate Keeper); Asmara (Horse Servant and possibly servant of Rathje); a pigs' keeper; Amlak Tärädda (Servant); Täfärra (Servant); Ašine (Servant); a cooking team; workers on the compound (with contract workers coming from outside). Altogether there had been about $4 \mathrm{O}^{-} 5^{\circ}$ persons on the compound. Campbell, The Plot, 122-123; the number (ca. 125) given here is an exaggeration.

PA-AA, GG 4O, Nr. o68, Bahlburg-Richter, o6.04.1937. For the life-saving activities of Bahlburg and the others, see later. $2-6 \mathrm{pm}$ could be approximately the time when he saved a group of priests who fled into Harmshusen. PA-AA, GG 40, Nr. o68, Rathje-Richter, 13.04.1937 (My Imprisonment). 
imprisonments and interrogations all happened on the same day, namely February 19. Campbell's dramatic narrative with unsubstantiated accusations against Bahlburg, therefore, falls apart due to the wrong chronology. ${ }^{51}$ His method of basing his information only on oral informants, who recalled a 'constructed' memory after more than half a century, without cross-checking their testimony with other available sources, needs to be seen critically.

During the 2-3 days he was in prison where he was interrogated twice under life-threatening conditions, Rathje steadied himself through faith and prayer. Finally, with the support of Bahlburg and the German Vice-Consul Richter, he was freed on 7 April $1937 .^{52}$ Səbhat had been methodically killed in prison by the Italians between 30 April-6 May $1937 .^{53}$ Hans Fricke, the newly appointed Consul, wrote to Bahlburg on 14 June 1937, attaching a letter from Colonel Alberto Mazzi to him, that all matters concerning Rathje could be considered settled. ${ }^{54}$

\subsection{Sobhat Tarunäh-His Ministry and Involvement in Resistance}

The missionaries were able to save the lives of many Ethiopians during the massacres, which will be described later. However, it was not possible for them to save their faithful co-worker, Səbḥatu, as they called him familiarly. ${ }^{55}$ Səbḥatu had been working for the GHM for about seven years (Easter 1930 until end of April 1937) as a teacher and evangelist, a translator and interpreter, as well as helping in administration, acquiring land and in defending Harmshusen from 2-5 May $1936 .{ }^{56}$

51 The two dates mentioned here support the fundamental critique against Campbell, The Plot, 237-240 and 253-26o, who narrates that all incidents took place on 19 February 1937. With this information, the reconstruction of this part of the history, including all assumptions and allegations, needs to be revised.

PA-AA, Pol 3:209, GG 40 Rathje, Richter (Aktenvermerk), 07.04.1937; A-ELM, BahlburgSchomerus, 793, 06.04.1937.

53 A-E LM, Bahlburg-Schomerus, 31.05.1937, written with more details from a safer distance in Aden.

54 PA-AA, Pol 3:209, GG 40 Rathje, Fricke-Bahlburg, 14.06.1937.

55 For a critical discussion of the point of view taken by Campbell, The Plot, see: Klein, The Reconstruction, 26-30. The main arguments against Campbell refer to the role of Səbhatu in the plotting, which has been overemphasized, and the expression "Hermannsburg Mission Group," which is misleading. Both will be clarified later.

$5^{6}$ According to Campbell, The Plot, 12-13, Səbḥat Tərunäh was born in 19o1, being the first son of Aläqa [Qes] Țərunäh Dästa and his first wife, who lived in the province of Gondär (Dära). Bahlburg wrote in A-ELM, Bahlburg-Schomerus, 16.05.1930, that Səbhat was a 19year-old man when he was introduced to him, therefore born in 1911. Bahlburg further: "His father is working as a teacher for the evangelical teaching in Gondär but has not left the 
He was a highly esteemed member of the 'spiritual family' on Harmshusen. ${ }^{\mathbf{5 7}}$ The documents of Bahlburg and Rathje give no indication that Səbhatu contributed to the preparation of the assault on Graziani. It seemed impossible for either of them to imagine that Səbhatu had been actively engaged in the plot. "Our Səbhatu has been sitting in prison for weeks, and we do not know if, and when he will be set free. Without any doubt, he has been politically suspected by the government without any reason. A dubious friendship has brought him under suspicion". ${ }^{58}$ "Səbḥatu has been with us for six years, and to

Abyssinian church." Qes Ṭərunäh was a member of a group of protestants that remained within Orthodoxy. He is identical with Qes Ṭərunäh Dästa in Arén, Envoys, 33: "A friend of theirs [Aläqa Tayyä Gäbrä Maryam (186o-1924) and Aläqa Täsäma Haylu—JK] named Qes Tiruneh (c. 1870-1933) took over the school at Dera [...]." See also: ibid., 41-45, 9596. Səbhatu, according to Campbell, arrived in Addis Abäba in 1926. He first went to the Täfäri Mäkwännən School (1926-1927) and then joined the Swedish Mission School for further studies (1927-1930). According to A-ELM, Bahlburg-Schomerus, 16.o5.193o, Səbhat started to work with the GHM around Easter 1930, because for the Swedish missionaries it was not possible to employ him as a teacher. The first confirmation celebration, a result of a small seminary work on Harmshusen, took place on 30 March 1932. On the back of a photo (A-ELM) taken on that day, Bahlburg wrote: "The other young man in the Abyssinian dress is our native teacher Sebhatu. Together with him I founded the seminary work. In teaching, he is a great help for Brother Schnack. He is a good evangelist and aware of his evangelical Christian faith. For some years the Swedes have educated him." According to AELM, Bahlburg-Schomerus, 27.01.1933, both Bahlburg and Səbḥat's father were together in the hospital, where Qes Ṭərunäh died early in January. He was buried in Addis Abäba, and Bahlburg released Səbhatu for three months to look for his relatives near Gondär. After the mourning period, he took his youngest brother Taddäsä Țərunäh to Addis Abäba and cared for him on Harmshusen (1933-1937). They first lived in a small hut, and later, according to Bahlburg in Privatarchiv der Familie Bahlburg (Private Archive of the Bahlburg Family, PA-в), Berlin, o6.05.1936, in a "[...] building with a kitchen and a native female cook, two native teachers and six orphans [...]" next to the building with the church and school. One teacher was Səbḥat, the other Mogäs Asgädom. In A-ELM, Rathje-Schomerus, "Aus meiner Arbeit," May 1935: "Our Evangelist Sebhatu understood it respectably to bring the Gospel of Christ close to them, because he himself was an upright Christian and knew his folk among whom he grew up. His father formerly had also been trained as an Evangelist and had been a teacher in the Abyssinian church." A-ELM, Rathje-Schomerus, 01.05.1935: "A great support is our native teacher Segatu [Səbhatu], who speaks German well." He gave sermons in Amharic during the Sunday afternoon worship, in which especially Orthodox Christians took part. Bahlburg reported in PA-B, Bahlburg-Schomerus, 16.12.1936, about plans to start a Bible School, where orthodox priests could participate to take part in local outreach programs, and Səbḥat would certainly have played an important role in its development.

57 For the term 'spiritual family', see next section 3.2.

58 A-ELM, AE 1.05, Bahlburg-Schomerus, 789, 30.03.1937. Campbell, The Plot, 153, supports this partially. 
our knowledge he has not been engaged in politics with either the Abyssinian or the Italian government." 59

Only in retrospect did they recognize that the friendship with Mogäs had become fatal for him. However, many Ethiopians in Addis Abäba and elsewhere had been engaged in the underground or indirect and passive resistance in one way or another. It is therefore very difficult to describe the extent of Səbhatu's involvement in those passive resistance activities, even though he was among the intelligentsia connected to the Täfäri Mäkwännən School and the Swedish Evangelical Mission (SEM). He had close relations with Qes Badəmma Yaläw (1885-1973), a friend of his father, who became Səbhatu's mentor and who had held responsible positions at the SEM, where Səbhatu had studied for about three years (1927-1930). Following the emperor's request that prayers be offered at all mission headquarters, Qes Badəmma gave a famous speech on Sunday, 4 August 1935, at the market place below the Qəddus Giyorgis Cathedral, where also the pupils of the SEM schools were present. ${ }^{60}$

In his family, patriotism played a pivotal role. ${ }^{61} \mathrm{His}$ father, Qes Tərunäh Dästa, was part of a 'protestant' movement within the Ethiopian Orthodox Church. The reminiscences of his younger brother Taddäsä Țərunäh (1924-2015) have certainly been influenced by this spirit in his reconstruction of history as given to Campbell. After everything Səbhatu had been through, his family felt he deserved to be honoured as a patriot. This may be the context of his brother's recollections that, nevertheless, need to be critically cross-checked. ${ }^{62}$ Yäkkatit 12 certainly was a fateful day for his brother Səbḥatu and his own life. Everything had to be explained from this perspective. Taddäsä Ṭərunäh and Campell filled in the missing information in their reconstruction of history. Səbhatu's fateful end had been described. Bahlburg, who tried to free him with a petition addressed to the Viceroy reported that he had been methodically killed by the Italians. ${ }^{63}$

59 A-AA, GG 40, Nr. o68, Rathje-Richter, 13.04.1937.

6o Arén, Envoys, 464 .

61 Campbell, The Plot, 74: "Sebhat Tiruneh's brother Tilahun [Təlahun Ţərunäh, JK] and cousin Teferi became Patriots. Tilahun joined Ras Desta Demtaw, and Teferi fought with the Balambaras (later, Ras) Abbebe Aregay in Shewa. Thus, Aleka Tiruneh's family became, in effect, a family of Patriots, and this tradition was to be a dominant influence in the lives of both Sebhat and Taddesse. However, Sebhat remained in Addis Ababa, and became, as we shall see a yewust arbeñña — an underground urban member of the resistance."

62 This has not been done satisfactorily by Campbell regarding the passages that deal with the GHM.

63 A-ELM, Bahlburg-Schomerus, 29.04.1937 and 07.05.1937. First Bahlburg did not mention 
In addition to what Campbell wrote about Səbhatu's involvement in the passive resistance, ${ }^{64}$ taking seriously into account his faith, nurtured by his father and the SEM, and framed by the teachings and theological convictions of the GHM on Harmshusen, it is questionable that Səbhatu was the 'initiator' of the underground resistance group that Campbell called the "Hermannsburg Mission Group." ${ }^{65}$ Despite his ill-fated end, both Bahlburg and Rathje held him in high esteem for years after the incidents. ${ }^{66}$ They remembered Səbhatu as a humble and deeply convicted Christian minister. ${ }^{67}$ His heart, like his father's one, was deeply connected with his brothers and sisters of the orthodox faith, with whom he always had had good relations.

Səbhatu on April 29, but on May 7 he wrote: "Səbhatu unfortunately died in prison because of typhus, and we are deprived of this faithful co-worker forever. He has done loyal services, which cannot be forgotten." The time of Səbhatu's death can therefore be dated between April 13, after Rathje's report about Səbhatu's condition (already affected in a prison by typhoid) and Bahlburg's report written on May 7, most probably toward the end of April 1937. A-ELM, Bahlburg-Schomerus, Aden, 31.05.1937, 7: "Almost 14 days after Səbḥatu's cruel death in a prison contaminated with typhus - we believe that he was brought to death methodically by subsidiary bodies of the investigation office-a secret policeman came with my plea for Səbhatu's liberation in his hand, which I wrote to the Viceroy. He was sent to make more inquiries about Səbḥatu, who already for longer had been in a mass-grave, we believe, probably eaten up by hyenas. It had not been considered necessary to inform us about his death. And he always was a valuable employee for us."

64 Campbell, The Plot, 489 (Index, Sebhat Tiruneh). For comments, see: Klein, The Reconstruction, 26-30.

65 Campbell, The Plot, 78-79, 9o-91, 105-107, 112-118, 122-131, 153, 158, 175, 181, 237-240, 247251, 453-454. For comments on Campbell's terminology, see: Klein, The Reconstruction, $42-46$ (footnote 180 ).

66 PA-B, Bahlburg-Schomerus, 14.08.1939: "Our Sebhatu—he unfortunately is dead—has personally made an enormous contribution to this success [...]," here referring to an acquisition of land for the enlargement of Harmshusen. Privatarchiv der Familie Rathje (Private Archive of the Rathje Family, PA-R), Sittensen, Rathje-Schomerus, 15.11.1939: "It still makes me very sad that our faithful Səbhatu has been taken away from us forcefully through a sudden death, since he was of good support here in our work among the Amhara."

67 The memory of Səbhatu has only recently been revitalized in the efforts of Cord Bahlburg, the youngest son of Hermann Bahlburg, and the author of this article. Cord Bahlburg handed over a collection of notes about Səbḥatu to his youngest brother Taddäsä Ṭərunäh in 2014. See PA-B, In memoriam of Sebhat Tiruneh, 2014. 


\subsection{The Imprisonment of Missionary Rev. Hinrich Rathje $e^{68}$}

Rathje's 11-page report, entitled Meine Verhaftung (My Imprisonment), was written on 13 April $1937 .{ }^{69}$ It is a detailed account of the events around Yäkkatit 12 in connection with the GHM, and on life-threatening aspects of his imprisonment. ${ }^{70}$ It provides rare insights into the techniques used during interrogation by the Italian secret police. Moreover, the report allows a reconstruction of the events around Yäkkatit 12 and its aftermath. Colonel Alberto Mazzi, Capo di Gabinetto (Head of the Cabinet), wrote that Rathje was taken to the Stazione dei Carabinieri Reali, to be interrogated by a Comandante, because there had been grave accusations against him that warranted a two-day investigation. The reason was the allegation, promulgated by spies, ${ }^{71}$ that he knew about or was involved in the preparations for the assassination attempt on Graziani. ${ }^{72}$ Con-

68 Hinrich Rathje arrived in Addis Abäba on $3_{1}$ October 1933, together with the nurse Eva Bartzsch. Soon he took over responsibility for the small Orphanage that started in 1931. Working closely together with Səbḥatu Țərunäh, who had been working formerly with teacher Heinrich Asmus, deacon Ernst Greb and missionary Rev. Willy Schnack, both Rathje and Səbhatu organized Amharic worship programs on Sunday afternoons. In addition, both Rathje and Sr. Bartzsch had social visit programs in the vicinity, often together with Səbḥatu for translation. Later, Rathje went to Bäddälle and Ayra for short periods of work, but returned to Addis Abäba together with Rev. Dietrich Wassmann, after spending a short time in Ğimma, to be interned by the British military, like Bahlburg, from 1941-1948. After the internment, he stayed in Germany from 1948-1954. He returned to Ethiopia in 1954 but fell sick again and went back to Germany after about a year, where he died in 1959. For other reports of Rathje's imprisonment, see: PA-AA, GG 4O, Nr. o68, Rathje, 1937; Bahlburg's reports PA-AA, Bahlburg-Richter, 06.04.1937 and A-ELM, Bahlburg-Schomerus, 31.05.1937; Dietrich Wassmann, Der Durchbruch des Evangeliums im Gallaland. Ereignisse und Erlebnisse nach dem italienisch-abessinischen Kriege 1936-1941 (Hermannsburg: Missionshandlung, 1948), 5-6-influencing Launhardt, Evangelicals, 78-79 and Bauerochse, Ihr Ziel, 269-271; Balázs, Fascist Italian Brutality, 138-139-influencing Campbell, The Plot, 257-26o. For the critical discussion of the point of view regarding Rathje's imprisonment taken by Campbell, The Plot, see: Klein, The Reconstruction, 37-40.

69 This report was discovered by the author of this article a few years ago at the Political Archive of the German Foreign Ministry, before other copies appeared. See PA-AA, GG 4O, Nr. o68, Rathje-Richter, 13.04.1937 (2nd version); for later versions, see: A-ELM, RathjeSchomerus, 07.04.1937 (1st version), and PA-R, Bericht von Missionar Rathje in Ethiopien über die schweren Tage seiner Verhaftung im April 1937 ("Report of Missionary Rathje in Ethiopia about the troublesome days of his imprisonment in April 1937") (3rd version).

70 Wassmann, Der Durchbruch, 5 , describes how the police threatened Rathje.

71 PA-AA, G G 40, Nr. o68, Rathje-Richter, 13.04.1937, 1. Since they caught some plotters and persons related to them, among them Səm'on Adäfrəs and Səbḥatu, interrogations may have laid the trail to Rathje. Rathje himself noticed that right after the assassination attempt, Harmshusen was surrounded by spies.

72 PA-AA, Pol 3:209, Mazzi-Fricke, o3.06.1937. Among the witnesses against Rathje were some spies, Amlak Tärädda, a servant that had been manipulated according to Rathje, and others who had been identified through the interrogations of Səbḥatu and Səm`on Adäfrəs. 
fessing to involvement in this kind of anti-Italian political activity could result in a prison or even a death sentence for him and the expulsion of the GHM with many dangers for the GHM members. Other plotters might also be imprisoned. ${ }^{73}$

It is not possible to give a full account of the report here. ${ }^{74}$ Rathje defended himself repeatedly referring to the mission's strict policy of non-political engagement and obedience to the God-given government based on Romans 13. This is a central part of the report. ${ }^{75}$

Bahlburg also referred to these principles in his briefings about Rathje's imprisonment in his letter to Bernardo Olivieri, and later in more detail in his letter to Christoph Schomerus. ${ }^{76}$ Due to the vehement advocacy of Bahlburg, speaking about the gentle personality of his colleague Rathje, and because of the official 'friendship' between the two countries, reinforced by Vice-Consul Herbert Richter, all allegations were finally dropped and Rathje was set free. ${ }^{77}$

\subsection{Hermann Bahlburg: Saving the Lives of Ethiopians as Part of the Resistance}

This section deals not only with the activities which saved Ethiopian lives during the days around Yäkkatit 12, but also with the circumstances under which these occurred. ${ }^{78}$ For the Italians, saving of Ethiopian lives would have meant that the GHM supported the resistance. Further, the Italians were looking for any possibility to get as many of the non-Italian missions as possible out of the country. From 19 February 1937 on, spies in service of the Italian intelligence tried anything to support their alleged suspicions. In return, the spies hoped to make a profit themselves. ${ }^{79}$

73 PA-AA, GG 40, Nr. o68, Rathje-Richter, 13.04.1937, 5-6, for the threats Rathje had been intimidated with.

74 Klein, The Reconstruction, 30-40.

75 A-AA, G G 40, Nr. o68, Rathje-Richter, 13.04.1937, 4.

76 PA-AA, GG 4O, Nr. o68, Bahlburg-Richter, o6.04.1937; A-ELM, Bahlburg-Schomerus, 31.05. 1937 .

77 PA-AA, GG 40, Nr. o68, Bahlburg-Richter, o6.04.1937; PA-AA, GG 40, Nr. o68, Rathje-Richter, 13.04.1937.

78 For a critical discussion of the point of view taken by Campbell, The Plot, see: Klein, The Reconstruction, 47-53. The main argument against Campbell focuses on his negative portrayal of Bahlburg, making him Səbḥatu's betrayer.

79 A-ELM, Rathje, 07.04.1937, 1: "Since a longer time we have been observed strongly by spies (Abessinians), who surrounded our place day and night, in fact already since the assassination attempt on Viceroy Graziani took place. [...] The espionage around our compound increased, and one has always seen people, who observed our people and questioned them about our work." 
The missionaries had to take a pro-Ethiopian stand and had to maintain good relations with the Italians to safeguard their mission work. The quotation of Rev. Hermann Bahlburg at the beginning of this article, written on 6 April 1937, points to this dilemma. ${ }^{80}$

Bahlburg was busy safeguarding the work of the GHM in Ethiopia, for which so many sacrifices had been made. ${ }^{81}$ For the leader it was a Drahtseilakt (a tight rope act), balancing between different interest groups without falling to either side.

The previous year Harmshusen had been attacked and had become a shelter for refugees. ${ }^{82}$ It was an ethical principle that the gates would be kept open for the wounded. The GHM had a sign of the Red Cross indicating its availability for support. ${ }^{83}$ The compound team was trained in taking in refugees with Sister Eva Bartzsch nursing many heavily wounded. ${ }^{84}$ This contributed significantly to saving lives around Yäkkatit 12.

8o Biographical notes about the life and work of Bahlburg are provided on the website hosted by the Bahlburg family at http://www.hermann.bahlburg.name. See Ernst Bauerochse, "Die Hermannsburger Mission in Äthiopien im Zeitalter des Totalitarimus," in Die Hermannsburger Mission und das "Dritte Reich" zwischen faschistischer Verführung und lutherischer Beharrlichkeit, ed. Georg Gremels (Münster: Lit, 2005), 129-139; Bauerochse, Ihr Ziel and Cord Heinrich Bahlburg, "Memorandum (2006) der Familie Bahlburg zum Konflikt der Hermannsburger Mission mit dem Missionar Hermann Bahlburg," in Der Weg einer heilsamen Erinnerung. Hermann Bahlburg 1892-1962. Zwischen Missionsdienst und Predigtverbot, ed. Georg Gremels (Hermannsburg: Ludwig-Harms-Haus, 2008), 28-29. Being at the age of 45 in 1937, Bahlburg, who grew up at Thelsdorf in the Lower Saxony's rural area of Germany, started his career as a blacksmith. In the middle of his theological studies at the Mission Seminary in Hermannsburg, he had been serving as a sergeant in World War I. Bauerochse, Die Hermannsburger Mission, 129, describes how the four years of military service shaped his mind. As described in Hermann Bahlburg, Aufbruch in der Heimat zum Gallaland. Anfänge der Hermannsburger Gallamission. Galla Sennung vun binn'n naoh buuddn (Hermannsburg: Selbstverlag, 1949), he completed his theological studies and later developed the Home Mission in Germany. After preparations, together with another theologian (D. Wassmann) and two handcraft missionaries (Adolf Müller and Hermann Grabe), the pioneer group arrived in Addis Abäba on 30 December 1927.

81 There are many letters and reports in which Bahlburg wrote about the dangers and threats of a possible end of the mission work in Ethiopia. Wassmann, Der Durchbruch, 118-124, describes this reality in more detail.

82 PA-B, Bahlburg, Tatsachenbericht über vier Kampftage auf der deutschen Hermannsburger Mission von Sonnabend, 2. Mai bis Dienstag, 5. Mai 1936 in Adis Abeba (Report of facts of the four days of fighting at the Hermannsburg Mission from Saturday, May 2, until Tuesday, May 5, 1936, in Addis Abäba), May 1936.

83 PA-B, Bahlburg, Tatsachenbericht, 2.

84 A-ELM, Bartzsch-Schomerus, 10.05.1936. 
It is also important to note that the Italian intelligence enforced strict censorship. ${ }^{85}$ The missionaries were not free to write about the events. There is, however, one report written by missionary Rev. Dietrich Wassmann (1897-1954) in his book published more than a decade later (1948). Wassmann based his memories on the time he returned to Addis Abäba from Germany at the end of January $1938,{ }^{86}$ and on various discussions he had with those who talked with him about the incidents. He wrote:

Missionary Bahlburg was able to save the lives of about 200 persons, including many priests of the Medani-Alem-Church, who took refuge on our compound Harmshusen, by quickly employing them for soil transport, when the policemen placed their machine-guns to shoot them down. [...] Although the natives' mistrust against all white people had increased because of the war experiences and even more after the horrible bloodshed, we as Hermannsburg people did not have to suffer. It was of greatest advantage that brother Bahlburg was successful in saving the lives of hundreds during the turmoil. Numerous Abyssinian priests with trembling knees experienced themselves how this was only possible at one's own risk with the utmost determination and intrepidity. ${ }^{87}$

85 A-E LM, Bahlburg-Schomerus, 31.05.1937, 3; Lass-Westphal, "Protestant Missions," 95: "Censorship of their letters [of the Swedish missionaries] had proved anti-Italian activity." On the strict censorship, see also: Campbell, The Addis Ababa Massacre, 104, who is quoting Sáska László (aka L. Sava) in Balázs, Fascist Italian Brutality.

86 Wassmann, Der Durchbruch, 11.

87 Wassmann, Der Durchbruch, 4-5, 9. This is confirmed by Winfried Wickert, Männer und Zeiten, 275: "Even many Abessinians were looking for and found protection on Harmshusen, and they did not forget what Bahlburg did for them." Wickert must have been informed about Ethiopian witnesses about their rescue, including the report of Bishop Hanns Lilje, who met an Ethiopian orthodox priest during one of his ecumenical meetings in England, who told him that he was one of the priests that Bahlburg saved in 1937. This narrative has also been kept and transmitted by Bahlburg's family, in PA-B, Freytag nee Bahlburg-Behrends, Email, 27.10.2008. Among the refugees who had been taken in was a group of priests. This is a significant detail in Wassmann's account. The Bahlburg family narrates that Bahlburg saw a group of about a dozen orthodox priests fleeing on Harmshusen. A new sport- and playground was under construction, so he gave the refugees tools. He stepped forcefully in front of the persecutors of carabinieri and 'blackshirts' and declared that the priests were workers he hired. No bullet was shot, and the priests were saved. Bahlburg may also have argued with the friendship between the Italians and the Germans. The family further heard that during an ecumenical meeting in England, Bishop Hanns Lilje from the Landeskirche Hannovers had been approached by an Ethiopian orthodox priest who told him, "I am one of the priests whose lives have been saved by Missionary Hermann Bahlburg back then in Addis Abäba." See PA-B, E. Freytag 
Wassmann in 1948 may have seized the opportunity to show that even though the GHM was allied with the Italians, it was nevertheless more concerned and allied with the Ethiopians. It was not pro-Italian against the Ethiopians, but pro-Ethiopian while keeping diplomatic relations of an official 'friendship' with the Italian regime for the sake of the continuation of the mission work. In order not to arouse the suspicions of the censors, the reports of Bahlburg and Rathje do not say much regarding the lifesaving activities. However, an indirect reading method or inferential process draws conclusions about their saving activities. Decoding these hidden intimations must be done cautiously. Bahlburg wrote that on Friday afternoon he went to 'the workers' to calm them down saying that he "[...] told them that they had nothing to fear against the Italians." 88 Bahlburg indirectly said here that he would protect them. Rathje in My Imprisonment, written on 13 April 1937 to Vice-Consul Richter, wrote about his second interrogation (6 April 1937), especially his reply to the question as to why he ordered the gate to be closed. "They should have kept the gates closed because we were not able to take all people in [sic!] and protect them." 89 Indirectly understood, this meant that they had taken in and protected a significant number of people already. These were so many that they were not able to take in more. This was the reason why the gates should have been closed..$^{90}$ This is a form of resistance because it counteracts the fascist plan of the Vendetta, intended to kill those Ethiopians that had been protected by the GHM.

\section{Some Important Aspects of Being Together in Resistance}

The policy of non-political engagement and having a social responsibility for the 'extended spiritual family' are two dimensions of the involvement of the GHM in resistance activities.

nee Bahlburg-Behrends, Email, 27.10.2018; ibid., L. Duschat nee Bahlburg, Notes telephone discussion, 25.12.2012.

88 PA-AA, GG 40, Nr. o68, Bahlburg-Richter, 06.04.1937 (Bahlburg-Olivieri).

89 PA-AA, GG 40, Nr. o68, Rathje-Richter, 13.04.1937 (My Imprisonment).

9o In an interview: Jürgen Klein, Interview, Addis Abäba 2018 (not published), Mahlet GäbräṢadəq, daughter of GHM driver Gäbrä Șadəq Wäldä Mika’el (ca. 1888-1963), reported that her mother Askale Dadi told her that refugees were streaming into Harmshusen, that the women and children were taken into the Unterstand, called waša (cave). When the situation calmed down, they silently went out through the gates on the western side toward the orthodox church. 


\subsection{The Policy of Non-political Engagement}

The principle of the GHM not to engage in politics but to focus only on wholistic evangelical work, based on the separation between church and state, and the obedience to God-given rule had all been put to the test around Yäkkatit $12 .{ }^{91}$

Both Bahlburg and Rathje highlighted the importance of not being allowed to get involved in political affairs. This was one of the basic principles of the Hermannsburg Mission, as taught by the founding father, Ludwig Harms. ${ }^{92}$

Bahlburg and Rathje both refer to Romans 13 of the New Testament in mentioning this. ${ }^{93}$ However, they were struggling to keep things in balance while having almost daily contacts with various interest groups, some of whom were politically-inclined such as the offices of the AOI, the German Consulate and the local NSDAP (Nationale Sozialistische Deutsche Arbeiterpartei) group in Addis Abäba. In the emergency case, when the question was whether to help the Ethiopians in need or support the Italians who were persecuting them, the missionaries felt obliged to apply the 'higher principle', namely loving God and 'the next.'

91 This was an ideal of high standards that must be seen critically in the light of the dilemma of a contextual reality, in which engagement with local people and relations with governmental offices often made it difficult to remain neutral. See the quotation at the beginning for this dilemma.

92 Hartwig Harms, Concerned for the Unreached. Life and work of Louis Harms, founder of the Hermannsburg Mission (Addis Ababa: Mekane Yesus Seminary, 1999); Jobst Reller, Heidepastor Ludwig Harms. Gründer der Hermannsburger Mission (Holzgerlingen: Hänssler, 2008).

93 PA-AA, Bahlburg-Richter, o6.04.1937: "My coworker, Herr Hinrich Rathje, and myself are presenting us to the Ufficio di giustizia militare as upright Germans and Christians, who so far and lifelong have been unsuspected and unblemished in domestic and foreign politics. As such, for about 80 years, our Hermannsburg Mission Society proved to be unsuspected and unblemished in domestic and foreign politics, and together with our homeland church seconded us on this compound in Ethiopia. In these institutions, in the spiritual ministry and office every kind of engagement in domestic and foreign politics is forbidden for us." PA-AA, Rathje-Richter, 13.04.1937: "Do you really believe that I did something against Italy? It is a principle of our German Hermannsburg Mission that we never engage politically. No, the contrary is the case. In our prayers on Sundays we also pray for you, and to our people we say that God said according to Romans 13: 'Everyone must submit himself to the governing authorities, for there is no authority except that which God has established'" See further: PA-AA, Bahlburg-Strohm, 20.10.1936; and A-ELM, BahlburgSchomerus, 31.05.1937: "It is therefore principally not difficult for us, being His servants in His work, to obey to the authority, which has power over us, but not all the power- that always remains reserved for Christ." Bahlburg refers to the supremacy of God and Christ in relation to other powers. 
The Lutheran doctrine, separating church and state, stood in contrast to Səbhatu's conviction based on the symbiosis of faith and nation. He came from a tradition of 'Protestantism within the Ethiopian orthodox identity', a Bible movement that his father, Qes Țərunäh Dästa, had taught him based upon a centuries-old tradition, which had its roots in the efforts of the Lutheran Peter Heyling in the ${ }^{17}$ th century, ${ }^{94}$ and was taken up by Aläqa Tayyä Gäbrä Maryam, Käntiba Gäbru Dästa and Qes Badəmma. Despite this, he kept his orthodox patriotic or nationalist identity. ${ }^{95}$ This mixture of being Ethiopian-orthodox in his protestantism (and vice versa), combined with patriotism, formed the backbone of Səbhatu's conviction and engagement.

\subsection{The Principle of Being a 'Spiritual Family' (Social Responsibility)}

A system of priorities or preference groups may help to briefly describe the invisible structure that steadied the missionaries from within.

The love of God is the nucleus around which the 'spiritual family' of Harmshusen forms the first-priority group of people. ${ }^{96}$ The second-priority group means those to whom the love to others in the mission is directed, namely the neighbors, the priests, and all those in need. This group can also be called 'extended spiritual family.' The third priority-group is the outer group with representatives of the government and others, who are not as important as the first and second group. The preference for the third (outer) group may be abandoned when the first or second (inner) group must be given priority. In con-

94 Otto Meinardus, "Heyling, Peter," in EAe 3 (2007): 27-28; Arén, Evangelical Pioneers, 34-38, 409-410; Manfred Kropp, "Ein äthiopischer Text zu Peter Heyling. Ein bisher unbeachtetes Fragment einer Chronik des Fāsiladas," in Proceedings of the Seventh International Conference of Ethiopian Studies, University of Lund, 26-29 April 1982, ed. Sven Rubenson (Addis Abeba: Institute of Ethiopian Studies, 1984), 243-256.

95 Ezra Gebremedhin, “Tayyä Gäbrä Maryam," in EAe 4 (2010), 88o-881; Arén, Envoys, 19-58.

${ }_{96}$ While navigating between groups with various interests, Bahlburg received orientation and orders from the home mission leadership in Hermannsburg. But he was also entrusted with some degree of local decision-making powers. Harms chose John 17:3 as the guiding motto of the Hermannsburg Mission. He believed that Christians cannot condone seeing others not taking part in the experience of God's love and love to one another through Christ. The love and compassion the mission staff expressed toward the Ethiopians stood next to the centre of serving God. This was the Christian principle of loving God (Gottesliebe) and loving the others or neighbours (Nächstenliebe) as images of Him. While the spiritual father was God, on Harmshusen the physical was Rev. Bahlburg, representing the mission founder Harms. For this understanding of roles, see: Harms, Concerned, 5658. In this understanding, Səbhatu and others were members of the 'spiritual family' The argument against the portrait of Bahlburg in Campbell, The Plot, focuses on these family aspects, and on the suppression of central spiritual aspects, when accusing him of having betrayed Səbḥatu. 
junction with this, the law of obedience to the government, based on Romans 13, and the principle of non-political engagement are superseded by the law of loving God and loving others, because they are the highest commandments. That was the case when Bahlburg, standing between the two priority groups, was protecting Ethiopian lives on the days of the massacre against the Italian system. However, later he had to write to the Italian General Olivieri, a representative of the third-priority group, about what happened on those days. To balance the diplomatic relations with this interest group, a different language was required to avoid any suspicion of supporting the Ethiopian people against the Italian system. This rather invisible structure and principle guided the GHM staff when they protected the Ethiopians.

\section{5}

\section{Conclusion}

Methods for the reconstruction of history must take seriously into account that oral transmission of (constructed) information needs to be double and triple cross-checked with all available written sources. Gaps resulting from a lack of information about historical events should not be filled in with private assumptions or allegations that could harm someone like Hermann Bahlburg (and his family) in retrospect as has been identified in Campbell's book The Plot.

Resisting together in view of the $\mathrm{GH}$ M first meant living together on the same compound. Having employed Səbḥatu, and having allowed Mogäs to be with him, led to unintended passive co-participation in resistance.

However, it is misleading to use the expression "Hermannsburg Mission Group" as a core resistance element, as claimed by Campbell. The missionaries were not part of those secret meetings, and if they would have known about them, they would have prevented them, based on their principles that they still adhered to at that time, namely the obedience to the government and not engaging in political activities.

Secondly, being together in resistance meant being together in confronting convictions. Both Səbhatu and the missionaries had different understandings regarding the relationship between religion and politics or church and state. Ecumenical dialogue in global interconnectedness encourages clarification of different theological concepts, both in Ethiopia and in Germany, and between orthodox and protestant convictions. Səbhatu was not able to cross the line from passive to active resistance. Based on this he eventually saved the GHM and the spiritual family, whereas it was not possible for the missionaries to save his life. He was struggling with his concept of faith and nationalism, keeping 
parts of the Ethiopian orthodox identity as a protestant Christian. For his convictions he became a martyr, worthy to be remembered for his faith.

Being together in resistance finally meant to help the needy in cases of emergency. It means to be a spiritual family that cares for the extended family, based on the commandment to love others, and ruling out secondary or tertiary priorities, if necessary. The spirit of this kind of family was recalled by Taddäsä Tərunäh, the younger brother of Səbḥatu, when he and Cord Bahlburg, the youngest son of Hermann Bahlburg, met in 2014. Looking back with sadness and good memories, almost go years old, he said: "We are still a family."97 Global interconnectedness in this sense creates a bond that lasts across space and time, and beyond Yäkkatit 12. Recently Cord Bahlburg was awarded the honorary membership of the Association of Ethiopian Patriots in commemoration of the life-saving activities of his father. This is yet another example of transnational interconnectedness.

Generally, there may be situations that lead to resistance following the demand to abandon a principle that is believed to be an essential one, like obedience to the government, by a more human and divine principle, born out of the commandment of love. The outcome of such resistance may be a sacrifice. However, it has the potential to overcome oppression, leading to more freedom.

\section{List of References}

Archiv des Ev.-Luth. Missionswerks in Niedersachsen e.V. (Archive of the EvangelicalLutheran Mission in Lower Saxony, A-ELM), Hermannsburg.

Politisches Archiv des Auswärtigen Amts (Political Archive of the Foreign Ministry, PAAA), Berlin.

Privatarchiv der Familie Bahlburg (Private Archive of the Bahlburg Family, PA-B), Berlin.

Privatarchiv der Familie Rathje (Private Archive of the Rathje Family, PA-R), Sittensen.

Ahmed Hassen Omer. "Mussolini and Islam in Ethiopia (1922-1941)." In Symposium "Cross and Crescent: Christian-Islamic Relations in Ethiopia," 23-26.09.2002, 7-15. Addis Abäba: Goethe Institute, 2002 (not published).

Aregawi Berhe. "Revisiting resistance in Italian-occupied Ethiopia. The Patriots' Movement (1936-1941) and the redefinition of post-war Ethiopia." In Rethinking Resis-

97 Jürgen Klein, Interview, Addis Abäba 2014 (not published). During the interview he said: "We are a family. Even though Hermann Bahlburg and Hinrich Rathje are dead, it is as if they were alive. We were and we are a family. After all, we are still a family." 
tance. Revolt and Violence in African History, edited by Jon Abbink, Mirjam de Bruijn and Klaas van Walraven, 87-113. Leiden: Brill, 2003.

Aregawi Berhe. "Spirit vs. War-machine. A Patriotic Resistance to Italian Occupation of Ethiopia (1936-1941)." Aigaforum, 02.27.2015: 1-18. URL: http://aigaforum.com/ articles/Ethiopian-Resistance.pdf.

Arén, Gustav. Envoys of the Gospel in Ethiopia. In the Steps of the Evangelical Pioneers 1898-1936. Stockholm: E Fs Förlaget, 1999.

Arén, Gustav. Evangelical Pioneers in Ethiopia. Origins of the Evangelical Church Mekane Yesus. Stockholm: E Fs Förlaget, 1978.

Axton, Matilda et al., ed. Foreign Relations of the United States Diplomatic Papers, 1936. Vol., 3, The Near East and Africa. Washington: United States Government Printing Office, 1953 .

Bahlburg, Cord Heinrich. "Memorandum (2006) der Familie Bahlburg zum Konflikt der Hermannsburger Mission mit dem Missionar Hermann Bahlburg." In Der Weg einer heilsamen Erinnerung. Hermann Bahlburg 1892-1962. Zwischen Missionsdienst und Predigtverbot, edited by Georg Gremels, 13-33. Hermannsburg: Ludwig-HarmsHaus, 2008.

Bahlburg, Hermann. Aufbruch in der Heimat zum Gallaland. Anfänge der Hermannsburger Gallamission. Galla Sennung vun binn'n naoh buuddn. Hermannsburg: Selbstverlag, 1949.

Bahru Zewde. "Abrəha Däboč̣." In EAe 1 (2003): 47.

Bahru Zewde. "Hagär Fəqər Tiyatər." In EAe 2 (2005): 966-967.

Bahru Zewde. A History of Modern Ethiopia: 1855-1991. 2nd ed. Addis Ababa: Addis Ababa University Press, 2005.

Bahru Zewde. Pioneers of Change in Ethiopia. The Reformist Intellectuals of the Early Twentieth Century. Oxford: Oxford University Press, 2002.

Bahru Zewde. Society, State and History. Selected Essays. Addis Ababa: Addis Ababa University Press, 2008.

Bairu Tafla. "Gäbrä Ggzi’abəḥer Dästa." In EAe 2 (2005): 6o6-6o7.

Balázs, Szélinger, ed. Fascist Italian Brutality in Ethiopia, 1935-1937. An Eyewitness Account by Sáska László (aka Ladislas Sava), translated from Hungarian by Meneczer Béla. Trenton: The Red Sea Press, 2015.

Bauerochse, Ernst. "Die Hermannsburger Mission in Äthiopien im Zeitalter des Totalitarimus." In Die Hermannsburger Mission und das "Dritte Reich," zwischen faschistischer Verführung und lutherischer Beharrlichkeit, edited by Georg Gremels, 127-140. Münster: Lit, 2005.

Bauerochse, Ernst. Ihr Ziel war das Oromoland. Die Anfänge der Hermannsburger Mission in Äthiopien. Münster: Lit, 2006.

Campbell, Ian. The Addis Ababa Massacre. Italy's National Shame. London: Hurst \& Company, 2017. 
Campbell, Ian. The Massacre of Debre Libanos. Ethiopia 1937. The Story of One of Fascism's Most Shocking Atrocities. Addis Ababa: Addis Ababa University Press, 2014.

Campbell, Ian. The Plot to Kill Graziani. The Attempted Assassination of Mussolini's Viceroy. Addis Ababa: Addis Ababa University Press, 2010.

Del Boca, Angelo. "Faschismus und Kolonialismus. Der Mythos von den 'anständigen Italienern'” In Völkermord und Kriegsverbrechen in der ersten Hälfte des 20. Jahrhunderts, edited by Fritz Bauer Institut, 193-202. Frankfurt am Main: Campus, 2004.

Del Boca, Angelo. The Ethiopian War 1935-1941, translated by P.D. Cummins. Chicago: Chicago University Press, 1969.

Ezra Gebremedhin. “Tayyä Gäbrä Maryam." In EAe 4 (2010): 880-881.

Gozaw Zäwdu. Commemorating Patriotism and a Short History of the Historical Heroes of the Ethiopian Patriots Association [in Amharic]. Addis Abäba, 2016.

Harms, Hartwig. Concerned for the Unreached. Life and work of Louis Harms, founder of the Hermannsburg Mission. Addis Ababa: Mekane Yesus Seminary, 1999.

Hussein Ahmed. "Islam and Islamic Discourse in Ethiopia (1973-1993)." In New Trends in Ethiopian Studies, Proceedings of the 12th International Conference of Ethiopian Studies, Michigan State University 5-10 September 1994, edited by Marcus Harold, 775-801. Lawrenceville, NJ: Red Sea Press, 1994.

Klein, Jürgen. The Reconstruction of Ethiopian History. The Involvement of the German Hermannsburg Mission in the Incidents around Yäkkatit 12. Forthcoming.

Kropp, Manfred. "Ein äthiopischer Text zu Peter Heyling. Ein bisher unbeachtetes Fragment einer Chronik des Fasiladas." In Proceedings of the Seventh International Conference of Ethiopian Studies, University of Lund, 26-29 April 1982, edited by Sven Rubenson, 243-252. Addis Abeba: Institute of Ethiopian Studies, 1984.

Lass-Westphal, Ingeborg. "Protestant Missions During and After the Italo-Ethiopian War, 1935-1937." Journal of Ethiopian Studies 10, no. 1 (1972): 89-101.

Launhardt, Johannes. “Amanu’el Gäbrä Śəllase.” In EAe 1 (2003): 217.

Launhardt, Johannes. Evangelicals in Addis Ababa (1919-1991): With special reference to Ethiopian Evangelical Church Mekane Yesus and the Addis Ababa Synod. Münster: Lit, 2004.

Marcus, Harold. A History of Ethiopia. Berkeley: University of California Press, 1994.

Marrassini, Paolo. “Kəbrä nägäśt.” In EAe 3 (2007): 364-368.

Mattioli, Aram. "Die vergessenen Kriegsverbrechen des faschistischen Italien in Lybien 1923-1933." In Völkermord und Kriegsverbrechen in der ersten Hälfte des 20. Jahrhunderts, edited by Fritz Bauer Institut, 203-226. Frankfurt am Main: Campus, 2004.

Meinardus, Otto. "Heyling, Peter." In EAe 3 (2007): 27-28.

Mersha Alehegne. "Pețros." In EAe 4 (2010): 140-141.

Mikre Sellassie Gebre Ammanuel. Church and Missions in Ethiopia in Relation to the Italian War and Occupation and the Second World War. Addis Ababa: Artistic Printing Enterprise, 2014. 
Norberg, Halldin. Swedes in Haile Selassie's Ethiopia, 1924-1952: A Study in Early Development Cooperation. Uppsala: Almqvist \& Wiksell, 1977.

Pankhurst, Richard. "Development in Addis Ababa during the Italian Fascist Occupation (1936-1941)." In Proceedings of the International Symposium on the Centenary of Addis Ababa, November 24-25, 1986, edited by Ahmed Zekaria, Bahru Zewde and Taddese Beyene, 119-139. Addis Ababa: Institute of Ethiopian Studies, 1987.

Pankhurst, Richard. "Events during the Fascist Occupation: Who was the third man?" Addis Tribune, 27.02.2004.

Pankhurst, Richard. “Yäţ̦ntawit Ityopya Ğägnočč Arbäññočč Maḩbär." In EAe 5 (2014): $35^{-} 36$.

Pawlos Ñoño. The Ethiopian-Italian War [in Amharic]. 2nd ed. Addis Ababa: Addis Ababa University Press, 2009 A.M.-2017.

Reller, Jobst. Heidepastor Ludwig Harms. Gründer der Hermannsburger Mission. Holzgerlingen: Hännsler, 2008.

Rubenson, Sven. "Badəmma Yaläw." In EAe 1 (2003): 429.

Salvadore, Matteo. "Mogäs Asgädom." In EAe 3 (2007): 984-985.

Sbacchi, Alberto. Legacy of Bitterness. Ethiopia and Fascist Italy, 1935-1941. Lawrenceville, NJ: The Red Sea Press, 1997.

Seltene Seyoum. "Resistance." In EAe 4 (2010): 379-381.

Thöndl, Michael. "Mussolinis Ostafrikanisches Imperium in den Aufzeichnungen und Berichten des Deutschen Generalkonsulats in Addis Abeba (1936-1941)." In Quellen und Forschungen aus italienischen Archiven und Bibliotheken 88, edited by Deutsches Historisches Institut in Rom, 449-488. Tübingen: Max Niemeyer Verlag, 2008.

Ufficio Superiore Topocartografico, ed. Guida Turistica di Addis Abeba, Riproduzione Vietata 1937 XV. Asmara: A Cura dell'Ufficio Stampa e Propaganda dell'A.O., 1937.

Wassmann, Dietrich. Der Durchbruch des Evangeliums im Gallaland. Ereignisse und Erlebnisse nach dem italienisch-abessinischen Kriege 1936-1941. Hermannsburg: Missionshandlung, 1948.

Wee, Paul. "Dietrich Bonhoeffer and Gudina Tumsa. Shaping the Church's Response to the Challenges of Our Day." In Church and Society. Lectures and Responses. Second Missiological Seminar 2003 on the Life and Ministry of Gudina Tumsa, edited by Gudina Tumsa Foundation, 15-51. Hamburg: WD L-Publ., 2010.

Welsch, Otto. "Befriedung und Aufbau in Äthiopien." Zeitschrift für Politik 27, no. 9 (1937): 535-542, URL: https://www.jstor.org/stable/43527536?seq=1\#metadata_info _tab_contents.

Westermann, Edward. "In the Shadow of War. German Loans and Arms Shipments to Ethiopia, 1935-1936." In New Trends in Ethiopian Studies, Proceedings of the 12th International Conference of Ethiopian Studies, Michigan State University 5-10 September 1994, edited by Marcus Harold, 1036-1050. Lawrenceville, NJ: Red Sea Press, 1994.

Wickert, Winfried. Männer und Zeiten. 5o Jahre Hermannsburger Missionsgeschichte. Ein Rückblick. Hermannsburg: Missionshandlung Hermannsburg, 1987. 